\title{
Improving the Learning Quality in the Vocational High Schools through the Implementation of Cooperative Learning Model
}

\author{
Sutopo, Paryanto, Aan Ardian, Arif Marwanto \\ Faculty of Engineering, Universitas Negeri Yogyakarta \\ Yogyakarta, Indonesia \\ sutopo@uny.ac.id.
}

\begin{abstract}
The purpose of applying the cooperative learning model within the study was to improve: (1) the vocational learning activities in the Department of Mechanical Engineering; and (2) the vocational student achievement in the Department of Mechanical Engineering. The cooperative learning models that had been applied in the study were the inquiry, the jigsaw, the think pare-share and the module model. Then, in conducting the study the researchers implemented the classroom action research method. The study was conducted in the Negeri 1 Seyegan State Vocational High School, Muhammadiyah 3 Yogyakarta Vocational High School, Muhammadiyah 1 Bantul Vocational High School and Negeri 2 Wonosari State Vocational High School. For the data collection, the researchers applied the observation, the testing, the documentation and the interview technique. Within the data analysis, the researchers made use of the Descriptive Quantitative Technique. The results of the study showed that: (1) the improvement of the vocational high school students' learning activeness has been equal to $27.56 \%$; and (2) the improvement of the vocational high school students' achievement has been equal to $31.26 \%$.
\end{abstract}

Keywords-learning quality, Department of Mechanical Engineering, cooperative learning

\section{INTRODUCTION}

A learning model or strategy will be appropriate if the model or the strategy can improve the educational quality. The educational quality might be manifested if the learning process has been conducted effectively; in other words, the teachinglearning process might be conducted fluently, appropriately and in accordance with the learning objectives. The criteria of an effective teaching-learning process are: (1) the teachinglearning process might develop the generalization concept and the abstract materials into the clear and solid matter; (2) the teaching-learning process is able to serve the different learning participants' development; and (3) the teaching-learning process involves the learning participants actively within the teaching so that the teaching-learning process might achieve the learning objectives in accordance with the programs that have been stipulated (Tabrani Rusyan, 1989).

Up to date the education domain, especially the one in the level of Vocational High School (VHS) around the Province of Yogyakarta Special Region, still encounters multiple problems.
The situation is apparent in the pre-observation activities that had been conducted previously. These problems are related to the learning process, the practicum tools availability, the students' learning motivation and the school's facilities. The problems related to the learning process include: the learning method that the teachers have applied has not been various and the teachers are still dominant in the learning process in the classroom so that they have not been able to develop the students' activities and creativeness. In addition, the learning media that have been operated have not been various and there are not many teachers who have been able to operate the attractive learning media in order to draw the students' attention. In relation to the practicum learning, almost $60 \%$ of the vocational high schools in Yogyakarta have some sort of drawback both in terms of quantity and in terms of quality in relation to the practicum tools that the schools have. As a result, achieving the actual competencies will be very difficult for the students. The schools also frequently encounter the low students' learning motivation. Indeed, most cases of the students' brawl in Yogyakarta has been conducted by the vocational high school students and, therefore, the vocational high school students' learning achievement tend to be lower in comparison to the senior high school students; these achievements might be viewed from the scores of National Examination that have been achieved. In relation to the available facilities, $40 \%$ of the vocational high schools still have the low facilities and, as a consequence, they have not been able to support the learning activities that have been conducted.

The problems that occur in the vocational high schools demand serious efforts in order to achieve the well-qualified learning process. Specifically in relation to the learning process and the low learning achievements that have been attained, these problems are not merely caused by the students; instead, these problems might also be caused by the learning methods that have not been able to optimize the students' potentials. The learning methods that have been applied have not been able to stimulate the students to be active during the lecturing session and, thereby, the two-way communication between the lecturers and the students has not been achieved. Thereby, there should be a learning method that might be appropriately implemented so that at least some of these problems might be overcome. 
Based on the brainstorming and the peer discussions, one of the learning alternatives that might worth for experiment and that might be considered being able to overcome multiple problems that have been mentioned above, as well as to accommodate the students' individual learning development, is the cooperative learning method. The cooperative learning method might provide opportunities into achieving the successful learning process. As the technology for instruction, the cooperative learning involves the students' active participation and minimizes the inter-individual differences. The cooperative learning eases the students to learn and to cooperate as well as to mutually contribute ideas and to take responsibility for the achievement o learning results both individually and cooperatively. Such learning model is in accordance with the principles of constructivist learning that puts the students and the learning subjects that should actively construct their knowledge so that the competencies that they should master might improve.

Multiple problems that have occurred in the vocational high school learning process might be formulated into the problem statements as follows: (1) How far might the cooperative learning method be implemented in order to improve the learning activities in the Department of Mechanical Engineering of the Vocational High School?; and (2) How far might the cooperative learning method improve the students' learning achievements in the Department of Mechanical Engineering of the Vocational High School? The study is an umbrella research with a topic that deals with the implementation of cooperative learning method into the vocational high schools. Then, the sub-theme of the study will the implementation of inquiry-type cooperative learning method, the implementation of jigsaw-type cooperative learning method, the implementation of the learning module and the implementation of think pair and share-type cooperative learning method. Each sub-theme of the study would be conducted by one university student as part of their undergraduate thesis.

To learn and learning are two interrelated concepts. To learn refers to the process of behavioural changes due to the interaction with the environment. The process of behavioural changes itself refers to the efforts that have been performed consciously based on the experiences when an individual interacts with the environment. The behavioural patterns that appear might be observed in the form of reaction as well as physical and mental attitude.

Essentially, to learn is conducted by anyone both the children and the adults. In the reality, there is a responsibility among the adults or the competent people to prioritize first the time, the space and the condition in order that the learning process might occur among the children. In this case, the learning process is expected to occur optimally among the learning participants through the designed manner and to be facilitated by the teachers in the schools. Therefore, there should be learning activities that the teachers should prepare.

Learning is a set of actions that have been designed in order to support the learning process among the learning participants by calculating the external events that play certain roles toward the sequence of internal events within the learning participants
(Winkel, 1991). Setting the learning events should be conducted carefully in order that the learning might be beneficial (Gagne, 1985). Therefore, the learning should be designed, the learning objectives should be formulated before the implementation and the learning implementation should be controlled (Miarso, 1993).

The beneficial learning process demands certain techniques, methods and approaches according to the characteristics of the objectives, the learning participants, materials and resources. As a result, there should be appropriate and effective strategies. Learning strategy is an art and knowledge of bringing the learning in such a way that the learning might achieve the objectives that have been stipulated effectively and efficiently (T. Raka Joni, 1992). The manners that are selected in designing the learning strategy include the traits, the scope and the action sequence that might provide learning experiences toward the learning participants (Gerlach and Ely). The teaching-learning strategies are not only limited to the procedures and activities but are also included the teaching material or packages (Dick and Carey).

The factors that influence the learning process consist of the internal and the external factors. The internal factors are the factors related to the personality of a teacher as the classroom caretaker. A teacher should be able to implement the learning process; therefore, a teacher should have mental preparedness, concordance between the tasks and the responsibilities, the material mastery, the good physical condition and the job motivation. On the other hand, the external factors are the conditions that occur or that come from the outer side of a teacher's personality namely family social environment within the community. The intended environmental factors are the factors of natural environment, the factors of social environment and the factors of the school environment.

According to M. Ngalim Purwanto (2004: 255), the learning quality might be viewed from the aspect of the process and the results of the learning process. From the aspect of the process, a learning process is said to be qualified if the overall or at least most of the learning participants $(75 \%)$ have been involved physically, mentally and socially within the learning process in addition to displaying the high learning desire. On the contrary, from the results of the learning process, a learning process is said to be qualified if the results of the learning process have been able to display the positive changes among the overall or at least most of the learning participants $(75 \%)$. Furthermore, a learning process is said to be successful and qualified if the evenly distributed input generates multiple and well-qualified outputs in accordance with the community needs, the community growth and the development.

Nana Sudjana (2002: 40) mentions that learning quality has been the effectiveness level of the learning process in achieving the learning objectives. Within the learning process, the main objective is the achievement of the learning objectives that have been formulated. In order to achieve the learning objectives, there should be the learning quality; in other words, in order to attain the optimum results, a lecturer should benefit the components of learning process optimally. Therefore, in order to improve the learning quality, a lecturer might pursue 
the improvement of learning motivation, learning activities, learning participants' creativity and learning discipline.

The learning activeness in the study is defined as the learning activities. As having been defined in the Kamus Besar Bahasa Indonesia (Anton M. Moeliono et.al, 1995) activeness might be defined as activities, routines or business. According to Ahmad Rohani (1995), the students' learning activeness include two aspects namely the physical (motor) activities and the psychic (mental, intellectual and social) activities. The physical activities refer to the condition that the students actively perform activities by using their body parts, creating something, playing or working; they are not only sitting while listening, viewing or just being passive. On the contrary, the psychic activities refer to the condition that the students' spirit is working and functioning mostly in the teaching activities. The physical activities refer to the concrete activities namely when the learning participants perform experiments, create model constructions and alike. Then, the psychic activities are apparent when the learning participants perform careful observation, solve problems and make decisions. Both of the aspects might not be separated from one to another and they complement one to another. According to Nana Sudjana \& Wari Suwariyah (1991: 20), the monitoring of students' activities in the active learning strategies contain the aspects of participation in the problem-solving, the responsibility within the task accomplishment, the cooperation and the learning motivation.

According to Kamus Besar Bahasa Indonesia (Anton M. Moeliono et.al, 1995), learning achievement is the mastery of the knowledge or the skills that will be developed by the subjects and usually the learning achievement is shown by the test or the scores that the teachers provide. Learning achievement has been the results of capacity change that includes the cognitive, affective and psychomotor aspect. Based on the definition, the researchers might draw the following conclusion about the learning achievement: learning achievement refers to the changes in the individual and includes the changes on the cognitive, the attitude and the psychomotor aspects that have been the evidence of certain efforts and that have been marked by the test scores provided by the teachers. From the explanation, the final conclusion will be that learning achievement refers to the level of students' capacity while they are attending the learning process in the school within a certain period of time.

The cooperative learning model is a sequence of learning activities that the students perform in certain groups in order to achieve the learning objectives that have been formulated. Slavin in Isjoni (2010: 15) states that cooperative learning is a learning model in which the students learn and work in small groups collaboratively and the members of each group are five people with heterogeneous structure. The cooperative learning helps the students a lot in learning and working together; they might contribute their ideas and take responsibilities in achieving the learning results both individually and communally. Different than the conventional learning, the main emphasis in both the collaborative and the cooperative learning is "learning together."
The structure of cooperative objective is characterized by the huge mutual dependence among the students within their groups. In the collaborative learning, the students say, "we as well as you," and the students will achieve their objectives only if the other students within the same group might achieve their objectives altogether (Arends, 1998; Heinich et al., 2002; Slavin, 1995; Qin \& Johnson, 1995).

The cooperative learning might provide the opportunities toward the successful implementation of learning practices. As a technology for instruction, the cooperative learning involves the active participation from the students and minimizes the inter-individual differences. The cooperative learning has added the momentum of formal and informal education from the two powers that meet each other namely: (1) the realization of practice, namely that the life outside the classroom demands the collaborative activities within the life in the real world; and (2) the development of awareness toward the social interaction in the efforts of manifesting the meaningful learning.

According to Johnson, at least there are five elements in order that a cooperative learning might occur within a group namely:

a. Positive interdependence. In the cooperative learning each student should sense that he depends and is bounded positively to the fellow group members with the following responsibilities: (1) mastering the learning materials; and (2) ensuring that each group member master the learning materials as well. They should sense that they will not achieve success if their fellow group members do not achieve success.

b. Inter-student direct interaction. The best learning results might be attained by means of inter-students' verbal communications that are supported by the positive mutual dependence. The

c. Individual responsibility. In order that a group of students might contribute, support and assist one to another, each student is demanded to master the materials that become the learning topics. Thereby, the each group member will be responsible for learning a topic materials and the results of group learning process.

d. Collaboration skills. The students' social skills are very important in the learning process. The students are demanded to have the collaboration skills so that in the learning process a dynamic interaction might be established for the sake of mutual learning and for serving as part of the cooperative learning process.

e. Group process effectiveness. The students process the effectiveness of their learning group by explaining which actions that might and that might not contribute to their learning process and by making decisions that might be followed up or that should be changed.

\section{METHOD}

The approach that the researchers selected was the Kemmis and Taggart-model classroom action research, namely a collaborative study based on the problems that occurred in the learning activities. The subjects in the study where the eleventh-grade students in the Negeri 1 Seyegan State Vocational High School, the Muhammadiyah 3 Yogyakarta 
Vocational High School, the Muhammadiyah 1 Bantul Vocational High School and the Negeri 2 Wonosari State Vocational High School. On the other hand, the objects in the study were the students' learning activeness and the students' learning achievements.

For the data gathering, the researchers implemented the observation, the test, the documentation and the interview. The data that had been gathered would be analyzed by means of descriptive analysis. The analysis included the calculation of mean score, standard deviation and percentage. Then, the results of the study toward each cycle would be elaborated quantitatively.

\section{RESUlTS AND DISCUSSIONS}

\section{The Implementation of Think and Pair (TPS )-Type Cooperative Learning Model}

The study for this cycle was conducted in the Negeri 2 Wonosari State Vocational High School. The subjects in the study were the eleventh-grade students from the Department of Welding Engineering and the number of the subjects were 32 respondents. The study was conducted in three cycles with the following results.

\section{The Implementation of the First Cycle}

From the results of observation toward the first cycle, the researchers found that during the learning process the activeness had been apparent among four students and the cooperation had been apparent among eight students; as a result, if the figures were turned into the percentage it would have been $12.50 \%$ (Very Poor) for the students' activeness and $25.00 \%$ (Poor) for the students' cooperation.

The category that had been attained in the first cycle was still under the target of achievement. The aspect of students' activeness and of students' cooperation belonged to the "Very Poor" and "Poor" category (61.00\% - 80.00\% on the table). The reason was that the students had not been accustomed to the TPS-type cooperative learning model and, therefore, most of the students were still confused about what they should do and they became passive during the learning process.

\section{The Implementation of the Second Cycle}

The data from the results of observation of the second cycle learning process were presented in the same manner as that of the first cycle, namely in the descriptive form and the quantitative data were in the form of numbers; furthermore, the quantitative data would be displayed with the qualitative sentences. From the results of the observation toward the second cycle, the researchers found that the activeness had been apparent among 25 students and the cooperation had been apparent among 17 students; if the figures were turned into the percentage it would have been $78.10 \%$ (Good) for the students' activeness and 53.10\% (Moderate) for the students' cooperation.

\section{The Implementation of the Third Cycle}

From the results of observation toward the third cycle the activeness had been found among 31 students and the learning, cooperation had been found among the 32 students. If the figures were turned into the percentage it would have been $96.90 \%$ (Very Good) for the students' activeness and $100.00 \%$ (Very Good) for the students' cooperation.

The improvement on the students' activeness and the students' learning cooperation in the first, the second and the third cycle might be viewed in the table of learning activeness improvement below.

TABle 1. Percentage on the Students' ACtiveness And LeARning COOPERATION IMPROVEMENT IN EACH CYCLE

\begin{tabular}{|l|l|l|l|}
\hline \multicolumn{1}{|c|}{ Cycle } & \multicolumn{1}{c|}{ Activeness } & \multicolumn{1}{c|}{ Cooperation } & \multicolumn{1}{c|}{ Mean } \\
\hline First Cycle & $12.50 \%$ & $25.00 \%$ & $18.75 \%$ \\
\hline Second Cycle & $78.10 \%$ & $53.10 \%$ & $65.60 \%$ \\
\hline Third Cycle & $96.90 \%$ & $100.00 \%$ & $98.45 \%$ \\
\hline $\begin{array}{l}\text { Average } \\
\text { Improvement }\end{array}$ & $42.20 \%$ & $37.50 \%$ & $39.85 \%$ \\
\hline
\end{tabular}

The percentage of each cycle in the table might be described in the following figure of improvement.

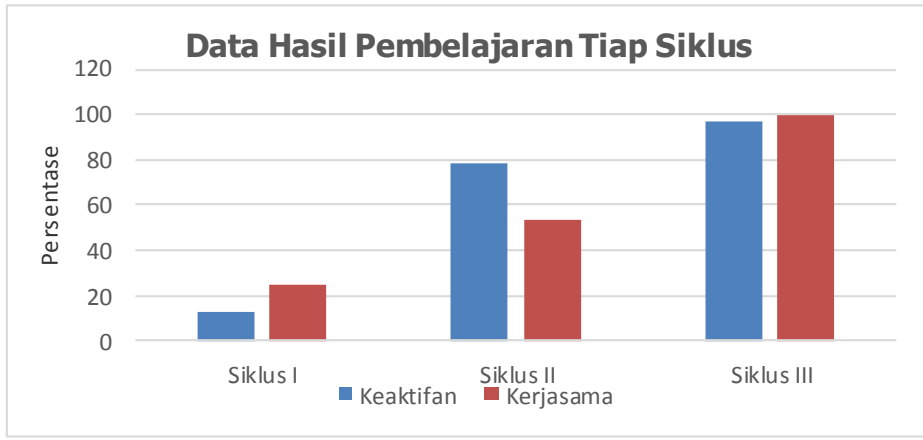

Fig. 1. Data on the Students' Activeness and Learning Cooperation Improvement in Each Cycle

\section{The Implementation of the Inquiry-Type Cooperative Learning Model}

The study for this cycle was conducted in the Muhammadiyah 3 Yogyakarta Vocational High School for four meetings. The subjects in the study were 17 students from the XMA class and 18 students from the XMB class. The object in the study, then, was the learning results of griping practicum.

In the first and the second meeting, the researchers scored the students' performance before applying the treatment to the two groups. Within the learning in the first and the second meeting, the students performed the practicum according to the materials that had been provided in the theoretical learning. Then, in the third meeting, the students were provided with a different method. The controlled group was provided with the conventional method namely the demonstration, while the experimental group was provided with the inquiry method. Next, in the fourth meeting, all of the students continued the practicum that they had conducted in the 
third meeting and at the end of the learning process the manufactured object should be submitted for assessment by the researchers.

Learning Results before the Treatment Application toward the Experimental Group

TABLE 2. Percentage FROM THE LEARNING RESUlts OF GRIPING PRACTICUM BEFORE THE EXPERIMENTAL GROUP TREATMENT

\begin{tabular}{|c|c|c|c|c|}
\hline No. & Indicator & Score & Total Score & Percentage \\
\hline 1. & Flatness & 35 & 108 & $32.00 \%$ \\
\hline 2. & Square-headedness & 49 & 216 & $23.00 \%$ \\
\hline 3. & Subtlety & 49 & 108 & $45.00 \%$ \\
\hline 4. & Size Accuracy & 13 & 54 & $24.00 \%$ \\
\hline \multicolumn{2}{|r|}{ Total } & 146 & 486 & $31.00 \%$ \\
\hline
\end{tabular}

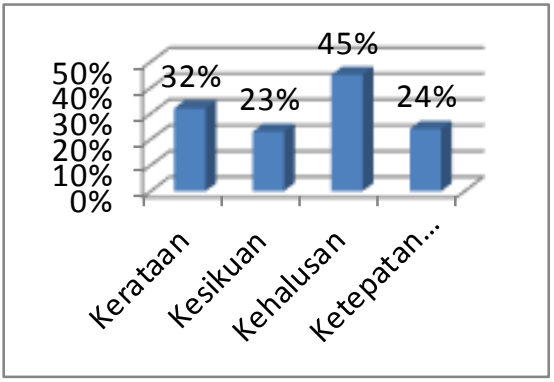

Fig. 2. Bar Diagram on the Percentage from the Learning Results of Griping Practicum before the Experimental Group Treatment

Learning Results before the Treatment Application toward the Controlled Group

TABLE 3. PERCENTAGE FROM THE LEARNING RESUlTS OF GRIPING PRACTICUM BEFORE THE CONTROLLED GROUP TREATMENT

\begin{tabular}{|c|c|c|c|c|}
\hline No. & Indicator & Score & Total Score & $\begin{array}{c}\text { Percent } \\
\text { age }\end{array}$ \\
\hline 1. & Flatness & 39 & 114 & $34.00 \%$ \\
\hline 2. & Square-headedness & 64 & 228 & $28.00 \%$ \\
\hline 3. & Subtlety & 46 & 114 & $40.00 \%$ \\
\hline 4. & Size Accuracy & 13 & 57 & $23.00 \%$ \\
\hline & Total & 162 & 513 & $32.00 \%$ \\
\hline
\end{tabular}

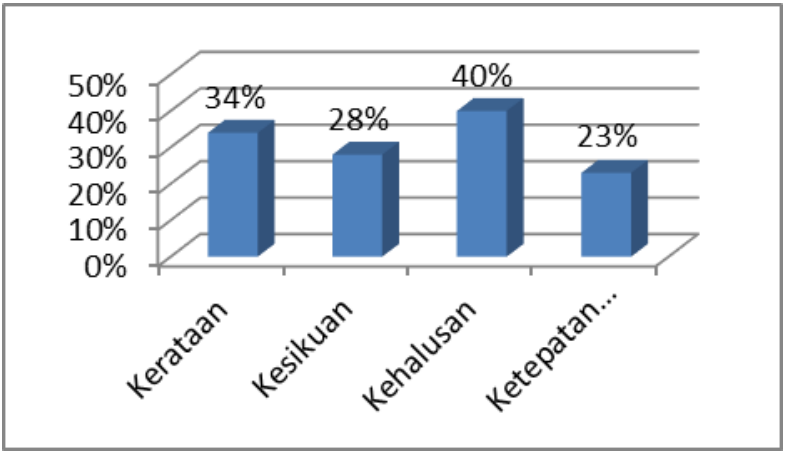

Fig. 3. Bar Diagram on the Percentage from the Learning Results of Griping Practicum before the Controlled Group Treatment

Learning Results after the Treatment Application toward the Experimental Group
TABle 4. Percentage From the Learning Results of Griping PRACTICUM AFTER THE EXPERIMENTAL GROUP TREATMENT

\begin{tabular}{|c|c|c|c|c|}
\hline No. & Indicator & Score & Total Score & Percentage \\
\hline 1. & Flatness & 65 & 108 & $60.00 \%$ \\
\hline 2. & Square-headedness & 119 & 216 & $55.00 \%$ \\
\hline 3. & Subtlety & 78 & 108 & $72.00 \%$ \\
\hline 4. & (Size Accuracy & 15 & 54 & $28.00 \%$ \\
\hline \multicolumn{2}{|r|}{ Total } & 277 & 486 & $57.00 \%$ \\
\hline
\end{tabular}

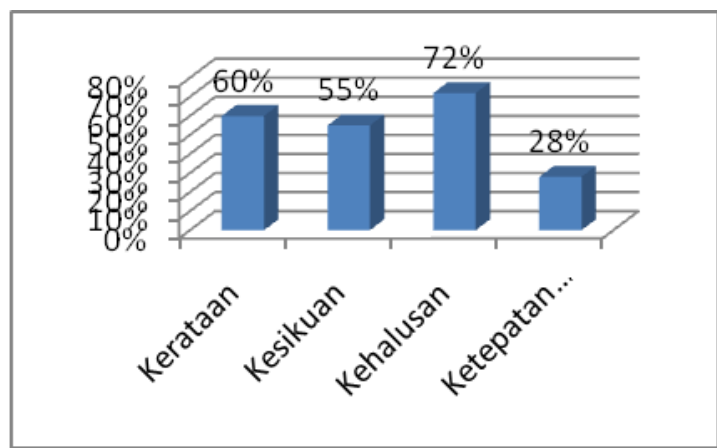

Fig. 4. Bar Diagram on the Percentage from the Learning Results of Griping Practicum after the Experimental Group Treatment

Learning Results after the Treatment Application toward the Controlled Group

TABle 5. Percentage From the LEARNING RESUltS OF GRIPING PRACTICUM AFTER THE CONTROLLED GROUP TREATMENT

\begin{tabular}{|c|c|c|c|c|}
\hline No. & Indicator & Score & Total Score & Percentage \\
\hline 1. & Flatness & 48 & 114 & $42.00 \%$ \\
\hline 2. & Square-headedness & 91 & 228 & $40.00 \%$ \\
\hline 3. & Subtlety & 54 & 114 & $47.00 \%$ \\
\hline 4. & Size Accuracy & 16 & 57 & $28.00 \%$ \\
\hline \multicolumn{2}{|c}{ Total } & 209 & 213 & $41.00 \%$ \\
\hline
\end{tabular}

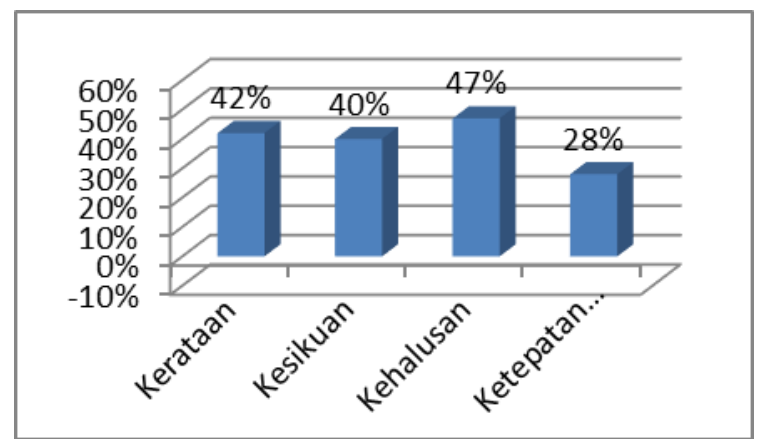

Fig. 5. Bar Diagram on the Percentage from the Learning Results of Griping Practicum after the Controlled Group Treatment

TABLE 6. THE RECAPITUlation ON THE PERCENTAGE FOR THE LEARNING RESULTS OF GRIPING PRACTICUM FROM THE CONTROLLED GROUP

\begin{tabular}{|l|l|c|c|c|}
\hline \multirow{2}{*}{ No. } & \multirow{2}{*}{ Indicator } & \multicolumn{2}{|c|}{ Percentage } & \multirow{2}{*}{ Improvement } \\
\cline { 3 - 4 } & & Before & After & \\
\hline 1. & Flatness & $34.00 \%$ & $42.00 \%$ & $8.00 \%$ \\
\hline 2. & Square-headedness & $28.00 \%$ & $40.00 \%$ & $12.00 \%$ \\
\hline 3. & Subtlety & $40.00 \%$ & $47.00 \%$ & $7.00 \%$ \\
\hline 4. & Size Accuracy & $23.00 \%$ & $28.00 \%$ & $5.00 \%$ \\
\hline \multicolumn{2}{|l|}{ Mean } & $31.25 \%$ & $39.25 \%$ & $8.00 \%$ \\
\hline
\end{tabular}


The recapitulation on the learning results of the griping practicum before and after the treatment, both for the controlled group and the experimental group, might be viewed in the following Table 6 and 7.

TABle 7. The Recapitulation On the PERCENTAGe FOR THE LEARNING RESULTS OF GRIPING PRACTICUM FROM THE EXPERIMENTAL GROUP

\begin{tabular}{|c|c|c|c|c|}
\hline \multirow{2}{*}{ No. } & \multirow{2}{*}{ Indicator } & \multicolumn{2}{|c|}{ Percentage } & \multirow{2}{*}{ Improvement } \\
\hline & & Before & After & \\
\hline 1. & Flatness & $32.00 \%$ & $60.00 \%$ & $28.00 \%$ \\
\hline 2. & Square-headedness & $23.00 \%$ & $55.00 \%$ & $32.00 \%$ \\
\hline 3. & Subtlety & $45.00 \%$ & $72.00 \%$ & $27.00 \%$ \\
\hline 4. & Size Accuracy & $24.00 \%$ & $28.00 \%$ & $4.00 \%$ \\
\hline Mean & & $31.00 \%$ & $53.75 \%$ & $22.75 \%$ \\
\hline
\end{tabular}

\section{The Implementation of the Jigsaw-Type Cooperative Learning Model}

The study for this cycle was conducted in the Muhammadiyah 1 Bantul Vocational High School and the study was conducted in two cycles. The actions that had been taken and the results that had been attained would be provided as follows.

\section{The Implementation of the First Cycle}

From the results of the test that had been conducted toward 36 students, the researchers attained the following data:

a. The students who had passed the minimum score were 23 people $(63.88 \%)$.

b. The students who had not passed the minimum score were 13 people (36.12\%).

The Results of Observation toward the Affective and the Psychomotor Aspect

TABLE 8. THE RESUlts OF OBSERVATION TOWARD THE AFFECTIVE AND THE PSYCHOMOTOR ASPECT

\begin{tabular}{|l|l|c|}
\hline No. & \multicolumn{1}{|c|}{ Indicator } & $\begin{array}{c}\text { First Cycle } \\
\text { Results }\end{array}$ \\
\hline 1. & $\begin{array}{l}\text { The students' encouragement in asking questions } \\
\text { and giving opinions during the learning process }\end{array}$ & $62.67 \%$ \\
\hline 2. & $\begin{array}{l}\text { The students' motivation in attending the learning } \\
\text { process }\end{array}$ & $66.33 \%$ \\
\hline 3. & $\begin{array}{l}\text { The students' interaction in attending the group } \\
\text { learning activities }\end{array}$ & $67.33 \%$ \\
\hline 4. & $\begin{array}{l}\text { The students' relationship with the teachers during } \\
\text { the learning process }\end{array}$ & $68.67 \%$ \\
\hline 5. & $\begin{array}{l}\text { The students' participation in attending the } \\
\text { learning process }\end{array}$ & $69.33 \%$ \\
\hline 6. & $\begin{array}{l}\text { The students' material mastery during the learning } \\
\text { process }\end{array}$ & $64.33 \%$ \\
\hline \multicolumn{2}{|c|}{ Mean } & $66.44 \%$ \\
\hline
\end{tabular}

From the classroom action research in the first cycle, the researchers attained the results that the students had not met the expectation because the benchmark indicator of success had been $70.00 \%$. Then, from the results of the interview with the teachers in the first cycle, the researchers found that the implementation of the jigsaw-type cooperative learning model had not been effective in the students' activities. Therefore, the researchers would like to implement the second cycle.

The Implementation of the Second Cycle

From the results of the test in the second cycle of 36 students, the researchers attained the following data:

a. The students who had passed the minimum score were 28 students $(77.77 \%)$.

b. The students who had not passed the minimum score were 8 students (22.23\%).

The Results of Observation toward the Affective and the Psychomotor Aspect

TABLE 9. The Results of OBSERVATION TOWARD THE AFFECTIVE AND THE PSYCHOMOTOR ASPECT

\begin{tabular}{|c|l|c|}
\hline No. & \multicolumn{1}{|c|}{ Indicator } & $\begin{array}{c}\text { First Cycle } \\
\text { Results }\end{array}$ \\
\hline 1. & $\begin{array}{l}\text { The students' encouragement in asking questions and } \\
\text { giving opinions during the learning process }\end{array}$ & $79.00 \%$ \\
\hline 2. & $\begin{array}{l}\text { The students' motivation in attending the learning } \\
\text { process }\end{array}$ & $84.33 \%$ \\
\hline 3. & $\begin{array}{l}\text { The students' interaction in attending the group } \\
\text { learning activities }\end{array}$ & $78.00 \%$ \\
\hline 4. & $\begin{array}{l}\text { The students' relationship with the teachers during } \\
\text { the learning process }\end{array}$ & $82.33 \%$ \\
\hline 5. & $\begin{array}{l}\text { The students' participation in attending the learning } \\
\text { process }\end{array}$ & $83.00 \%$ \\
\hline 6. & $\begin{array}{l}\text { The students' material mastery during the learning } \\
\text { process }\end{array}$ & $83.67 \%$ \\
\hline & \multicolumn{2}{|c|}{ Mean } \\
\hline
\end{tabular}

The passing grade percentage on the students' learning results in the evaluation of the first cycle had been $68.30 \%$ and of the second cycle had been $77.77 \%$; the percentage in the second cycle implied that the students' learning results had met the indicator of success benchmark namely $70.00 \%$. The improvement on the passing grade percentage in the students' learning results had been equal to $13.89 \%$. Similarly, the students' activeness had been equal to $81.72 \%$ and, as a result, the indicator of success benchmark had also been achieved. The improvement on the students' activeness had been equal to $15.28 \%$.

\section{The Implementation of the Learning Module-Type Cooperative Model in the Form of Metal Fabrication Molding and Manufacturing}

The implementation of the learning module had been the sequence of module development process. After having been considered valid by the experts, the module then would be implemented as the learning materials within the learning activities. The subjects of the implementation where the 28 eleventh grade students from the TP 1 Class as the experimental group and 29 eleventh grade students from the TP 3 Class as the controlled group; these students were selected 
from the Negeri 1 Seyegan Vocational High School. The implementation of the learning module was conducted for four times within one month. Then, for the process of the module implementing the researchers made use of the quasiexperimental design.

\section{The Students' Pre-Test Results}

The pre-test toward the TP 1 Class students and the TP 3 Class students were conducted in the form of task and practicum provision that had been written in the module. The percentage of the passing grade for the TP 1 Class students had been equal to $42.86 \%$, while the percentage of the passing grade for the TP 3 Class students had been equal to $41.38 \%$. These percentages might be better viewed in the following figure.

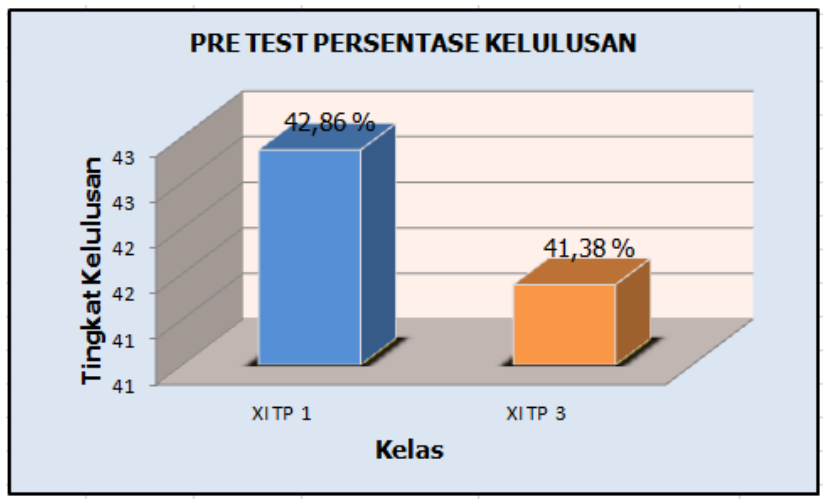

Fig. 6. The Students' Pre-Test Results

\section{The Students' Post-Test Results}

The module experiment was conducted toward the TP 1 Class students in order to identify the comparison between the TP 3 Class students as the controlled group and the TP 1 Class students as the experimental group. The students' post-test results would be depicted in the following figure.

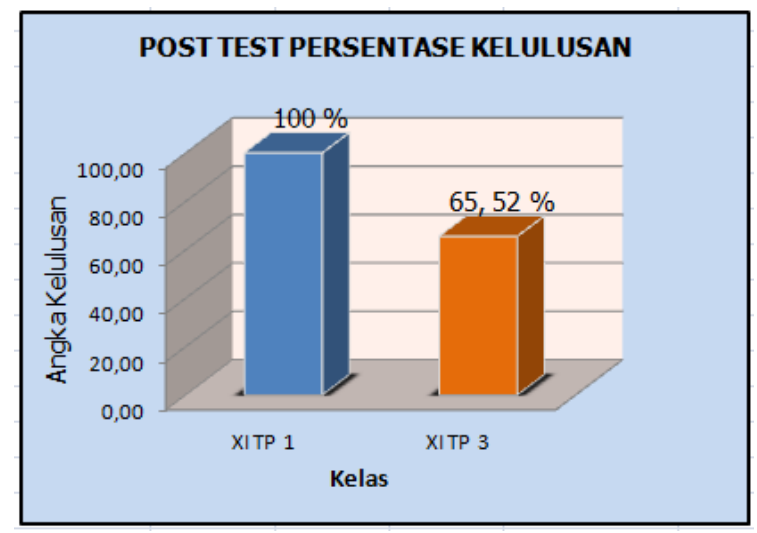

Figure 7. The Students' Post-Test Results

\section{Module Effectiveness}

After the Metal Fabrication Molding and Manufacturing Module had been implemented in the TP 1 Class (the experimental group), the effectiveness on the passing grade improvement had been equal to $57.14 \%$. After the assessment had been done, the comparison between the experimental group and the controlled group had been equal to $36.00 \%$. The difference in terms of improvement between the experimental group and the controlled group had been high.

TABle 10. The Improvement AFTER The Post-Test Results

\begin{tabular}{|l|l|l|l|l|}
\hline No & Kelas & \multicolumn{1}{|c|}{ Pre-Test } & \multicolumn{1}{|c|}{ Post Test } & Kenaikan \\
\hline 1 & XI TP 1 & $42.86 \%$ & $100.00 \%$ & $57.14 \%$ \\
\hline 2 & XI TP 3 & $41.38 \%$ & $65.52 \%$ & $21.14 \%$ \\
\hline \multicolumn{4}{|l}{ Comparation } & $36.00 \%$ \\
\hline
\end{tabular}

The above table showed that the improvement on the passing grade for the TP 1 Class as the experimental group had been equal to $57.15 \%$ and the TP 3 Class as the controlled group (using the old-fashioned system) had been equal to $21.14 \%$.

Learning had been a process of changing the situation from now knowing anything into knowing something. The changes might be found in the students' knowledge, behaviours or skills. The factors that influenced the students' learning process were the ones of learning approach. The learning approach within the students might include the strategy and the method that had been applied, the availability of learning facilities and the social, political, scientific and technological environment.

Learning activeness referred to all sort of activeness, both the physical one and the mental, that occurred during the learning process. The students' learning activeness and cooperation consisted of the visual activities, the oral activities, the listening activities, the writing activities, the motor activities, the mental activities and the emotional activities.

Learning model referred to the guidelines or the procedures for a teacher or an educator in planning and implementing the learning activities. The cooperative learning model had been one of the learning models that afforded to manifest the active, creative, effective, inspirational, challenging and fun learning process. One type of the cooperative learning model in the study was the TPS model. Within the implementation, the learning model had several stages that should be implemented.

The use of cooperative learning model might be a new learning process in the educational domain for several vocational high schools. Up to date, the method that has been implemented in the learning process is the conventional method in which the teacher serves as the source of knowledge that provides explanations and the students only serve as the listeners and take notes on the materials that the teacher distribute. Such situation has caused the students to be passive in the learning process. The cooperative learning model aims to involve the students so that they will be active in the learning process.

Based on the results that had been explained above, the researchers would like to recapitulate the improvement on the students' activeness and the students' learning achievement 
after the implementation of cooperative learning method as follows:

a. In the implementation of the TPS-type cooperative learning model, the students' activeness in the first cycle had been equal to $18.75 \%$, in the second cycle had been equal to $65.60 \%$ and in the third cycle had been equal to $98.45 \%$. Based on the data, the mean percentage of the improvement of the students' activeness during the learning process had been equal to $39.85 \%$. Similarly, in the implementation of the Jigsaw-type cooperative learning model the students' activeness in the first cycle had been equal to $66.44 \%$ and in the second cycle had been equal to $81.72 \%$. Based on the data, the mean percentage of the improvement of the students' activeness during the learning process had been equal to $15.28 \%$. Therefore, the researchers would like to conclude that the average improvement on the students' activeness during the learning process by means of cooperative learning model represented by the TPS-type and the Jigsaw-type cooperative learning model had been equal to $27.56 \%$.

b. In the implementation of Inquiry-type cooperative learning model, the students' learning achievement in the experimental group before the treatment application had been equal to $31.00 \%$ and after the treatment application had been equal to $53.75 \%$. The improvement of the students' learning achievement through the implementation of the Inquiry-type cooperative learning model had been equal to $22.75 \%$. On the other hand, in the implementation of the Jigsaw-type cooperative learning model the students' minimum passing grade in the evaluation of the first cycle had been equal to $63.88 \%$ and of the second cycle had been equal to $77.77 \%$. The percentage showed that the students' learning results had met the indicator of success benchmark and the improvement on the students' learning results had been equal to $13.89 \%$. Similarly, within the module implementing the students' pre-test results in the experimental group had been equal to $42.86 \%$ and the students' post-test results in the experimental group had been equal to $100.00 \%$. The improvement in the students' learning achievement had been equal to $57.14 \%$. Thereby, the average improvement in the students' learning achievement after the implementation of cooperative learning model represented by the Inquiry-type, the Jigsaw-type and the Learning Module Implementationtype cooperative learning model had been equal to $31.26 \%$.

Based on the above results, the implementation of the cooperative learning model had been proven to be able to improve the learning quality in the vocational high schools. The improvement in the learning quality had been marked by the improvement of the students' learning achievement or results and the students' learning activeness. By implementing the cooperative learning method, the researchers had been able to provide the opportunities for the students and to stimulate the students to keep performing activities and to stay focused in the learning process; automatically, the students' understanding of the learning materials that had been distributed would be more maximum. Eventually, the cooperative learning model would enable the students to attain the maximum learning results.

\section{CONCLUSIONS}

Based on the results of the study that has been conducted, the researchers would like to draw the following conclusions:

1. The implementation of the cooperative learning model might improve the students' learning activeness in the vocational high schools for about $27.56 \%$.

2. The implementation of the cooperative learning model might improve the students' learning achievement in the vocational high schools for about $31.26 \%$.

\section{REFERENCES}

Ahmad Rohani \& Abu Ahmadi. (1995). Pengelolaan Pengajaran. Jakarta : PT Rineka Cipta.

Anton M Moeliono. et al. (Eds). (1995). Kamus Besar Bahasa Indonesia. Jakarta : Balai Pustaka.

Arends, R. I. (1998). Learning to teach (4th ed.). Boston, MA: McGraw-Hill.

Gagne, L. N. (1985). Educational psychology. Chicago: Rand McNally.

Isjoni. (2010). Pembelajaran Kooperatif Meningkatkan Kecerdasan Komunikasi Antar Peserta Didik. Yogyakarta: Pustaka Pelajar.

Johnson, D.W., R.T. Johnson and M.E. Stanne. (1995). Cooperative Learning Methods: Meta-Analysis. University of Minnesota Press, Minneapolis, MN.

Kemmis, Stephen, Mc Taggart, Robin. (1998). The action research planner. Victoria: Deakin University Press.

M. Ngalim Purwanto. (2004). Prinsip-prinsip dan teknik evaluasi pengajaran. Bandung : Remaja Rosdakarya.

Miarso, Y. (1993). Desain pembelajaran: Teori dan Terapan. Malang: FPS IKIP Malang.

Nana Sudjana. (2002). Dasar-Dasar Proses Belajar Mengajar. Bandung : Sinar Baru.

Nana Sudjana \& Wari Suwariyah (1991). Model-Model Mengajar CBSA. Bandung : CV Sinar Baru Bandung.

Raka Joni, T. (1992). Pokok-pokok pikiran mengenai pendidikan guru. Jakarta: Konsorsium Ilmu Pendidikan, Direktorat Jenderal Pendidikan Tinggi, Departemen Pendidikan dan Kebudayaan.

Slavin, R. E. (2005). Cooperative learning. (2nd ed.). Boston: Allyn and Bacon.

Thobroni, Muhammad dan Mustofa, Arif. (2011). Belajar dan Pembelajaran. Yogyakarta: Ar Ruzz Media.

Winkel, WS. (1991). Psikologi pengajaran. Jakarta: PT. Gramedia. 